\title{
PARINI ON TOLSTOY, WITH A POSTSCRIPT ON TOLSTOY, SHAKESPEARE, AND THE PERFORMING ARTS
}

This review of Jay Parini's novel The Last Station appeared in one of the early issues of a newly founded forum in the Slavic field, the Tolstoy Studies Journal (TSJ), issue 3 (1990). Twenty years later, in preparation for the Tolstoy Centenary and also for Michael Hoffman's acclaimed film, I re-read the novel - and found it wonderfully good, better than my somewhat condescending and nit-picking commentary below. Excepting minor upgrades in grammar and some shifting of footnote material into the main text, the review is reprinted without change. But it is followed by a postscript where Hoffman's The Last Station (starring Christopher Plummer and Helen Mirren as the Tolstoy couple) is the starting point for further thoughts on the more general question of a "performed" and performing Tolstoy, one that includes adaptations of the novels, productions of Tolstoy's plays, and (inevitably) "productions" of the writer's life. While working through these paradoxes, I was enormously helped toward my hypothesis by Tolstoy's implacably hostile attitude toward Shakespeare.

\section{REVIEW OF JAY PARINI'S THE LAST STATION: A NOVEL OF TOLSTOY'S LAST YEAR (1990)}

Jay Parini. The Last Station: A Novel of Tolstoy's Last Year. New York: Henry Holt and Co., 1990. 290 pp.

Parini's novel is the sort of book that almost begs to be dismissed by professionals in the field. We know too much, and there is too much to know. Parini's task was too easy (that "Tolstoy's life is a novel" is a great truism). The real life characters themselves wrote up - indeed, over-wrote up - the events of that last year from every conceivable angle; and for potting around in this rich earth, the novel has already received too many wildly positive reviews. This first impulse to reject on our part would be a mistake. Jay Parini 
has done a very creditable job, achieving in his portrait of a deeply divided and estranged Yasnaya Polyana such moments of translucent paralysis that the reader must take a deep breath just to push on.

Parini's technique - surely the correct one to apply to a colony of graphomaniacs engaged in a war over diaries and memoirs - is to alternate chapters from the pen, or point of view, of the major participants. He surrounds Tolstoy with five distinct spheres of influence and commentary: Sofya Andreyevna, Dr. Makovitsky, Valentin Bulgakov, Vladimir Chertkov, and the youngest Tolstoy daughter and most ardent disciple, Sasha. These five persons are all to one extent or another "novelized," that is, although the events they relate in "their" chapters are documentable and familiar, Parini has filled them in, motivated them, added inner and outer dialogue. But there are two other types of chapter as well. The first type, entitled "J. P.," consists of Parini's own lyrics, which serve to suspend tensions for a page or two at critical points. The second, labeled "L. N.," are excerpts from Tolstoy's own writings (letters, diary entries, the final scene of "The Death of Ivan Ilyich"). Clearly these two initialed chapter-types belong to a special category of authoritative voice - to, as it were, real authors. Parini respects this difference between himself/Tolstoy and everybody else in the novel by inserting Tolstoy "whole" and on his own; in these lofty "L. N." chapters, Tolstoy's texts are reproduced without contextualization or commentary. Others at Yasnaya Polyana always risk Parini's intervention, but the sage is allowed to speak absolutely for himself. (A check of the Tolstoy letters and diaries quoted by Parini indicates for the most part unabbreviated, and - with one or two inexplicable exceptions ${ }^{1}$ - accurate direct quotation.) Tolstoy, it seems, can create fictions, even fictions of himself, but he is not a victim of them.

1 The major "inaccuracy" occurs on Parini's p. 30, ch. 19 ("Chertkov"). Chertkov is recalling a treasured letter he had received from Tolstoy dated November 7, 1884, in which Tolstoy recalls his unfinished novel about Peter I. The explanation Tolstoy gives of Peter's evil deeds was that the tsar was "simply too busy" building ships, working the lathe, making proclamations. He recommends for Chertkov "a little more calm and idleness." Tolstoy writes (in R. F. Christian's translation): "It's a truism that idleness is the mother of vice; but not everyone knows that feverish, hasty activity is the handmaiden of discontent with oneself and especially with other people." This point is reversed in Parini's truncated version of the sentence, which reads: "It's a truism that idleness is the handmaiden of discontent with oneself and, in particular, with other people."

The error is unfortunate, for it not only reduces Tolstoy's good counsel to a banality but misses a chance to prefigure Tolstoy's mature doctrine of "non-doing" as a route to the avoidance of evil. It is, I believe, over-clever to assume that readers of Parini's novel would recognize this compression - or interpret it as a suppression of memory on the 
No one senses the unfairness of this better than Sofya Andreyevnain my opinion the novel's finest, although by no means fairest, creation. At one point she is trying to win Valentin Bulgakov to her side; she knows she has nothing to win, and her bitterness and jealousies run so deep that she could hardly work with her winnings if she made them. She begins by praising the young secretary:

"I think it surprises him that such a young man could be learned. When he was your age, he was whoring in the Caucauses."

The dear boy cleverly ignored my derisory remarks about Lyovochkaa good sign. Tact is among the more socially useful forms of insincerity. It is noticeably lacking among my husband's associates. Lyovochka, of course, has never had to worry about not offending people. If you are Leo Tolstoy, you merely reveal the Truth (67).

In that paragraph there is so much anger, helplessness, wounded pride and awareness - so much, in short, of Dostoevsky's Underground - that one can only involuntarily admire her ability to survive at all. It is not the sort of sympathy transmitted, say, by Louise Smoluchowski's spousal biography Lev \& Sonya. ${ }^{2}$ We have moved far beyond that. With Sonya it is a matter of animal desperation, and Parini has a poet's ear for patterns of entrapment as an older woman might feel them: the fading of her body as an endpoint for Tolstoy's interest, the exhaustion of over a dozen pregnancies, a morbid weariness about the present interrupted by long stretches of absolute lyrical recall of the past. Sonya's wandering memory gives the novel most of its historical dimension. And the results are disastrous, because that sort of remembering leads her into traps like "...I will triumph. Our love will triumph." "Our love" is now solely her possession.

The other characters are also successful, but shallower. There is the embittered and God-ridden Dushan Makovitsky; the translucently inexperienced Valentin Bulgakov, a marvel of mental balance; Chertkov, ungenerous and manipulative but - like so few of the others - utterly attuned to Tolstoy's needs in the present; and ponderous Sasha, combining

part of the rigidly doctrinaire and unforgiving Chertkov, always ready to correct Tolstoy into his own version of a "Tolstoyan."

There are also a few liberties in chronology that do not seem to be motivated by any special novelistic intent. On Parini's p. 173 (ch. 25, "L. N."), the famous letter to Sofya Andreyevna of 14 July 1910 is dated 14 June; likewise, some of the diary entries are only approximately dated.

2 See the review of Smoluchkowski's 1987 book by Stephanie Sandler in TSJ 1 (1988). 
her mother's tenacity with her father's intellectual stubbornness. The image of Tolstoy himself through these various lenses is quite fine, most of all for its being very old. Its closest competitor is the marvelous portrait that Vsevolod Meyerhold recalled in the mid-1930s to his theater company, in connection with their planned production of Pushkin's Boris Godunov and the sly, severely moral character of the monk Pimen. The octogenarian Tolstoy is key to Pimen, the great director mused. He described to his troupe his pilgrimage to Yasnaya Polyana some three decades earlier. Meyerhold had been in awe, gazing at a spot high on the door where the great man was bound to appear: "... at last the door opened and in came this little figure in a black overcoat and a yarmulke, a little man like this, and with teeny little steps he headed off somewhere, to go the bathroom or someplace. Tolstoy turned out to be a dried-up, little old man. I was speechless..."3 Parini, too, is good with age. For all the patience, humility, and authority of Tolstoy's own writing in the "L. N." chapters, through others' eyes we see a frail, revered and very stubborn old person, one who cannot abide change in any ritual or personality except at his own initiative, and who deeply needs at all times a rapt audience. Chertkov with his Tolstoyan colony on call and Makovitsky with his endless pious note-taking understand and cater to this. That they are the least attractive characters in the novel must give us pause.

Here the underside of Parini's "authoritative" strategy is revealed. In giving Tolstoy's voice that uninterrupted and unmediated status in the novel, he suggests to the reader - or to this reader - that a steady diet of "confession in diary form" is a pretty poor way to grow if your goal is a Tolstoyan one. The well-known letter to Sofya Andreyevna from 14 June 1910 (which Parini reproduces as his ch. 25) makes this very clear. First there is the problem of love. "I have never stopped loving you," he writes, even though he then insists that all the possibilities for active love had disappeared (a half-century earlier, at work over the three-part typology of love in chapter 24 of Youth, Tolstoy would not have allowed himself to say this). Then there is the problem of private narrative itself. If you feel misrepresented, Tolstoy writes to his wife, "I shall happily take this opportunity to say, in my diary or in this letter, what my relations with you were really like, and what your life has been, as I have seen it." Sonya is right: in this format all her husband ever has to do is "reveal the Truth." Everyone else, in their chapters, must put up with messy dialogue on the spot.

See the rehearsal notes in Paul Schmidt, Meyerhold at Work (Austin: University of Texas Press, 1980), 120-21. 
Parini is familiar with the translated primary documents of the period, a formidable body of writing to organize. What could we possibly add? The traces of life and thought left by the Tolstoy clan and their associates are so articulate, lucid and self-aware that one wonders how any later writer could improve on them - short of trimming, juxtaposing, in essence assembling a collage. There's an element of that in this book, although this fact should in no way detract from the creative achievement (the balance and the beautiful writing) of the novel.

A more serious criticism, however, is that Parini-with the great iconoclast and nay-sayer Leo Tolstoy as his subject-has written such a conventional novel. It succeeds in communicating and skillfully foreshadowing all those things that Tolstoy polemicized so passionately against, pointing to truths, or more often to paradoxes, that the reader must ponder in the most painful "one-way" contexts. But still it is a novel replete with scenes of sexual voyeurism, that sine qua non of the genre (the virgin Bulgakov being deflowered by green-eyed Masha at Telyatinki, a very boring story; Dr. Makovitsky recalling an act of oral sex with a Hungarian prostitute, his one experience with women; the initially subtle and then leaden intimations of lesbianism between Sasha and Varvara Mikhailovna). All these activities might well have gone on, but biographical novels leave a lot out and it would have been better if some of those descriptions had been, well, left out. They distract and coarsen the texture. Parini is so excellent with the traces of things, with those situations that require restraint and register tiny, terrible shifts of mood. He understands best how old and worn-out things keep on living, and even get miraculously revived (the old Tolstoy on the train, suddenly surrounded by a rapt audience, is one example). But perhaps the inclusion of the body in its young and spontaneously erotic forms is Parini's final challenge to Tolstoy - and to Tolstoy's disgust at novels that pander to the ready market for such scenes. If so, the strike is cruelly on target.

One might consider Parini's book in connection with the meditative Finale to George Eliot's Middlemarch. "Marriage, which has been the bourne of so many narratives, is still a great beginning," she writes. "It is still the beginning of the home epic - the gradual conquest or irremediable loss of that complete union which makes the advancing years a climax, and age the harvest of sweet memories in common." It is doubtless truer, as George Eliot sensed, to end a novel on old age than on happy weddings. And what about real life? Parini's novel shows us the Tolstoy family at work undermining both beginnings and ends, with the only way out an absolute reinvestment in the old man's written texts. If those texts weren't so extraordinary, it would be a bitter harvest. 


\section{POSTSCRIPT TO PARINI AND HOFFMAN, 2010: SOME THOUGHTS ON TOLSTOY IN THE PERFORMANCE MODE, WITH A DIGRESSION ON TOLSTOY AND SHAKESPEARE} (2010)

Hoffman's film adaptation of The Last Station was greeted rapturously. The all-star cast proved equal to its world-class subject matter. It's even likely that Tolstoy himself, with his instinct for showmanship and keen interest in the potential of cinema for the presentation and communication of feelings, would have sighed and stayed glued to the screen. For moving pictures, he said, were a wondrous thing. Although he figures among the world's greatest wordsmiths, Tolstoy never doubted that the truth of a situation was sooner in the movement of minds and bodies than in the words that so clumsily mimicked that movement. Tolstoy was not a cultist about language, and in his view, the ability to write bestowed upon a person no special virtue. Writing too well could even be a trap. This is perhaps the surest proof that Tolstoy was not - in the metric, metaphoric, and prophetic sense - a poet, but some other sort of creator.

The Last Station the Movie also received appreciative reviews from academics "inside the industry." To be sure, some did carp on what could only strike a Tolstoy specialist, a tolstoyeved, as grating errors or mistakes in judgment (along the lines of my corrective first footnote on Parini's novel in the 1990 review). In a recent discussion of the film, for example, Professor Michael Denner, editor of the Tolstoy Studies Journal and currently at work on a short biography of Tolstoy, identified some of these "minor factual flaws... more irritating than consequential": "Almost to a one, the pronunciation of estates and family names is butchered, and many of the Russian signs are misspelled. (Could the set designers really not find a single educated Russian to help out? The Russian director Andrei Konchalovsky, Nikita Mikhalkov's brother, is listed as a producer.) The estate in Saxony where the film was shot is far swankier than dowdy Yasnaya Polyana, and the huge train station where Tolstoy dies in the film is nothing like the shack where Tolstoy actually died." ${ }^{2}$ Previous jointly-advised films of nineteenthcentury classics (Martha and Ralph Fiennes's Eugene Onegin from 1999 comes to mind) suggest that such inflation in architecture, landscape, provincial elegance and other visual pomp might be the Russians looking

$4 \quad$ Michael Denner, “Stop Scribbling!” Chteniya (Spring 2010): 122. 
back nostalgically to their aristocratic imperial age, exaggerating its elegance so as better to set off the shabby socialist century that followed. Or do people really think that Russia outside its cities (even today) has villages kept up like German or Swiss towns, with trimmed cemeteries and mowed lawns?

Denner noted the handsomeness and radiant bulk of the leading role. Christopher Plummer is a charismatic human being, as was his real-life subject - but, Denner remarks, "Tolstoy was a tiny man, more a restless electron than the dominating proton of Plummer's screen presence." To this I would add two things. First, "Sasha" (the youngest Tolstoy daughter, Alexandra Lvovna) was altogether too slender, too glamorous; the Tolstoy women were beetle-browed and fat, and in general the family, while extremely fertile, was not a handsome one. At some level this coarseness pleased Tolstoy. And second, Tolstoy's teeth. He had lost most of them by his late twenties. Tolstoy's diary records episodes of gazing glumly into the mirror at his rotting stubs. It was a delicate point. In the fiction, a sure sign that a man (even an unworthy man) is a serious rival is when he reveals a row of "strong, compact teeth," such as graced the mouth of Count Alexei Vronsky. Tolstoy so often seems to frown or pout in his photographs, especially in those many late, sternly prophetic portraits arranged by Chertkov — and toothlessness must have contributed. Tolstoy was not a humorless man; he loved pranks and responded with infectious delight to jokes. But Plummer's dazzling fullfrontal octogenarian smile is not, and cannot be, Tolstoy.

Part of this biographical quibbling might just be the humanities professoriat wondering why the outside world so rarely knocks at its door to get things right (when it matters, as it does here; the real-life Count Tolstoy felt miserable about living in luxury, after all — and this movie makes it look like he really was). Part might be due to the principled disregard in Englishspeaking countries, and England especially, for any "foreign prejudices" in the pronunciation of other nations' sounds (Melancholy Jake-wess and Don Jooen are canonical, but why the near certainty that every British production of a Chekhov play will put the incorrect stress on half of the names over two syllables?). Since these decisions are not matters of taste or interpretation but simply wrong, it is mystifying for those who know Russian why we English speakers go out of our way to make them. But Denner remarks on more serious liberties, which scandalize the wretched participants of the year 1910 even more than the facts warrant. Sofya Andreyevna had indeed faked a few suicide attempts that summer, and she was miserably, hopelessly jealous in a situation where that emotion was simply not effective. But she never fired a gun at Chertkov's portrait. 
In reviewing Hoffman's adaptation, the general press divided its attention between what was stunning in the quasi-fictional film and what was stupefyingly unacceptable in the historical Tolstoy. A. N. Wilson, in the Times Literary Supplement, admires the landscape and the actors, but like Denner laments the fact that "Christopher Plummer is far too genial. (And far too handsome - could not the make-up people have shoved a blob of putty on to Plummer's fine nose?)"5 About the geniality, Jay Parini, in a post-film interview, appears to agree. ${ }^{6}$ It is unfortunate, however, that so few reviewers attend in any detail to Parini's novel or its relation to the film built off it. Wilson plays indirect tribute to that primary written source text - and to the fact that it was composed out of even more primary written texts - in his discussion of the singularly cruel letter that Tolstoy penned on May 13, 1909 and then filed away for his wife to read after he was gone. "The letter is a good example of how the Tolstoys by now conducted many of their deadliest assaults on one another in writing," Wilson notes shrewdly. "They did not want their disagreements to be things of the moment, or their marital rows to evaporate in the air. And one of the comically deft things about the Hoffman film is that in most scenes someone or another is keeping notes, or writing the conversations down. At several points Sofya bursts out in protest or tries to snatch the notebook from the copytaker's hand." Wilson is right, the scenes are both hilarious and unbearable. As Tolstoy pursues his quest for universal love and brotherhood, words are forever being tested and found wanting - but words, especially written-down words, remain the overwhelmingly authoritative medium of choice. And the more they hammer the cosmic ideal in place, the more they document its failure closer to home. "Having spent the first part of his creative life fashioning experience into story," Wilson remarks of the Master, "he spent the second half making his own life into a sort of grotesque parable."

5 A. N. Wilson, "Despite his faults: Two Cinematic Versions of Late, Great Tolstoy [The Kreutzer Sonata, The Last Station]," Times Literary Supplement (February 19, 2010): 17-18, esp. 18.

$6 \quad$ See "Interview with Jay Parini" conducted by William Nickell (author of The Death of Tolstoy: Russia on the Eve, Astapovo Station, 1910 [Cornell University Press, 2010]) in Tolstoy Studies Journal XXI (2009): 67-73, esp. 73: “Christopher Plummer is a brilliant, classically trained actor, and he's the right age. And he's got a kind of gravitas and warmth. In fact I think he has a warmth in the film that I somehow doubt that Tolstoy had in real life. To be quite frank, increasingly when I look back at Tolstoy and read him I come to the conclusion that he was a real pill... I was left with the impression, having spent six months rereading Tolstoy last year, that the guy was a pill, and a fairly humorless pill." 
This parable was acted out in Yasnaya Polyana - to an incalculably large audience. By his final decade, Tolstoy had become the world's most "imaged" literary celebrity, routinely spied on in the paths and bushes of his estate by reporters with new-fangled recording equipment, the technological miracles of the first media revolution. In the film, this sense of performing live to an instant and rapt international audience is superimposed on the scribbling note-takers of Tolstoy's inner circle. That world had literally become a stage, its men and women players. Perhaps to remind the movie-goer that Tolstoy wanted out of this world but also (like all great reformers and performers in possession of a precious script) wanted readers and spectators to watch him and listen to what he had to say, Wilson devotes a full half-column of his TLS review to Tolstoy's "notorious essay" on Shakespeare and on drama. This Elizabethan connection is my bridge from Hoffman's film to more general comments on Tolstoy and the proper stage performance.

One final review will set the scene. In his discussion in The New Yorker in December 2009, David Denby discusses The Last Station with insight and sympathy. The astonishing Helen Mirren is everywhere praised in this "most emotionally naked work of her movie career," where "she gives poetic form to the madness and the violence of commonplace jealously... letting her age show and still the most sexual actress onscreen." When her husband rises to the bait in the right ways, for a few minutes Sofya Andreyevna lives on; but he is easily her superior in self-control and articulation, so mostly she is undone. "Plummer, who is turning eighty himself, effortlessly suggests largeness of spirit even in foolish old age," Denby writes. "Like a great night at the theater, the two performing demons go at each other full tilt and produce scenes of Shakespearean affection, chagrin, and rage."7 This is a fine focal point, given Tolstoy's disgust toward Shakespeare as a dramatist.

The best-known part of Tolstoy's polemic against the Bard is his travesty of the plot of King Lear that opens his 1903 screed "On Shakespeare and on Drama," later made famous by George Orwell's 1947 essay on it, "Lear, Tolstoy and the Fool." ${ }^{\prime}$ But Tolstoy's dislike had begun decades before, long before

$7 \quad$ David Denby, “Love Hurts," The New Yorker (December 14, 2009): 96-98, esp. 96.

$8 \quad$ George Orwell, "Lear, Tolstoy and the Fool" (1947), in Shooting an Elephant and Other Essays (New York: Harcourt, Brace \& World, 1950), 32-52. Prefiguring the tensions in Hoffman's film, Orwell suggests that Tolstoy's horror at King Lear was in part due to its autobiographical resonance (stubborn father, faithful daughter, the rest of the homestead a nest of plotters): "The subject of Lear is renunciation... The most impressive event in Tolstoy's life, as in Lear's, was a huge and gratuitous act of renunciation. Lear 
that treatise and the family scandals of 1910. Other aspects of Shakespeare repelled Tolstoy more thoroughly than the senseless second-hand plots, of which he found King Lear a most sorry example. Tolstoy was an artist. And in his view, what qualified Shakespeare's dramaturgy most of all as "counterfeit art" was its unrelieved eloquence and constant striving for sensational verbal effects. Even when they should be struck dumb with horror, even when on the edge of murdering or strangling others, Shakespeare's characters keep talking, in an uninterrupted string of witty, profound statements. Tolstoy was especially offended by the culminating scene of Othello, a work that he otherwise considered one of the Bard's "least bad plays." "Othello's monologue over the sleeping Desdemona, about his desiring her when killed to look as she is alive, about his intending to love her even dead, and now wishing to smell her 'balmy breath,' etc., is utterly impossible. A man who is preparing for the murder of a beloved being does not utter such phrases..."9

This remark à propos of the jealous Moor is a good example of what prompted A. N. Wilson, in the paragraphs of his TLS review dealing with this inflammatory topic, to call Tolstoy's reading of Shakespeare "grotesquely wrong" (17). It is that, without a doubt. And the short defense, should one wish to mount it, is that Tolstoy did not accept the conventions of Renaissance staging or stage language, its metaphorical extravagance as well as its non-illusionist Choruses and prefatory bards. ${ }^{10}$ What feels most wrong in Tolstoy's treatise on Shakespeare, however, is not its opinions, which Tolstoy is free to profess in his own name, but its contempt for others' opinions, its insistence that anyone who reacts otherwise to the English playwright is drugged, hypnotized, duped, in the blind grip of "epidemic suggestion" propagated by a self-serving press, not in his right mind, only pretending to like it. Such a tactic appears to come with the territory of the Tolstoyan personality, and no amount of assumed humility can bleach it out. Tolstoy denies others the dignity of their own reactions on behalf of his

renounces his throne but expects everyone to continue treating him as a king. Tolstoy, like Lear, acted on mistaken motives and failed to get the results he had hoped for" (43-45).

$9 \quad$ See "Tolstoy on Shakespeare," by Leo Tolstoy, translated by V. Tchertkoff and I. F. M., Followed by "Shakespeare's Attitude to the Working Classes" by Ernest Crosby and a Letter from G. Bernard Shaw (New York and London: Funk \& Wagnalls Company, 1906). No rights reserved, 65-66. Translation slightly adjusted.

10 In his essay "Leo Tolstoy, Subverter of Shakespeare" [«Лев Толстой - ниспровергатель Шекспира»], Alexander Anikst notes correctly that if we turn everything Tolstoy rejects into a positive sign, we have a perfect recipe for Elizabethan theater. Aleksandr Anikst, “Lev Tolstoi - nisprovergatel' Shekspira," Teatr 11 (1960): 42-53. 
commitment to brotherhood - his deep desire that every mind and body, once cleansed of pollutants, would think and feel as his did — and this vision was a linchpin of his life's work not soon to be dislodged. More genre-specific to his loathing of Shakespearean drama was his belief that lengthy moral self-presentation through words, monologues of inner self-searching, were not appropriate for the stage.

As Tolstoy told Teneromo [Isaak Fainerman] in an interview in 1907, such inward-gazing psychology was the task of novels, not drama. A theater audience would find it "boring, tedious, artificial" [«скучно, нудно, и неестественно»]. ${ }^{11}$ Thus Tolstoy was not interested in those words, or passages, in Shakespeare that paralleled his own moral searching or echoed his personal ethical stance on power, mortality, fidelity, war. Edmund in King Lear on not blaming astrology for our freely-chosen vices, Isabella on political power in Measure for Measure, Helena on stubborn active love in All's Well that Ends Well, Macbeth on human fate, the soldiers Williams and Bates on war (to their disguised sovereign on the eve of the Battle of Agincourt in Henry $V$, an episode reflected in War and Peace), Coriolanus on the vagaries of loyalty, Hubert in King John against the murder of princes, Prince Hamlet on fear of death: the content of these magnificent monologues is full of Tolstoyan wisdom, but Tolstoy refuses to register it. It is almost as if he did not hear them - or rather, did not read them, for his acquaintance with Shakespeare was largely through print. He attended live performances rarely, and only to persuade himself that the plays were as bad as he remembered them to be.

Without the psychological insights of the monologues, Shakespeare might indeed seem a sensationalist shell for the "animal in man," the purely zhivotnoe. But the ubiquitous lust and violence of Renaissance plots could not have been the only irritant for Tolstoy. As regards on-stage enactment of cruelty, Tolstoy's own play The Power of Darkness - in which a newborn child is methodically crushed to death over several minutes - rivals the tortures of King Lear or even the mutilations that stud a revenge tragedy like Titus Andronicus. (Tolstoy was aware of this vulnerability in his peasant drama and provided a less graphic variant for his fourth act; but he retained the murder taking place in story time). Apparently it is not the violence of the deed itself that is offensive to Tolstoy. Nor are words alone to blame. Tolstoy's nonacceptance of Shakespeare comes to a head over the relationship of words to deeds on stage, over what we might call Tolstoy's sense of the morality 
of a performing genre. In certain situations, eloquence cannot go on. At a certain point, deeds must make us mute. Words cannot be allowed to "pretty up" a deed and make it compelling, whether for animalistic reasons or spiritually lofty ones. Matryona is evil in The Power of Darkness because she has a smooth, wise-sounding folk saying ready for every situation - just like a Shakespearean Fool, the target of Tolstoy's special scorn. ${ }^{12}$ It doesn't matter whether the Fool speaks falsehoods or truths.

Tolstoy's most reliable righteous people are inarticulate: stutterers, bunglers, shy, ill-spoken, like Alyosha the Pot. That the upright old man Akim in The Power of Darkness is a stutterer was crucial to Tolstoy. As he wrote in March of 1887 to Pavel Svobodin, the actor in Petersburg's Aleksandriiskii theatre who would be playing Akim: "He speaks with a hesitation, and then suddenly phrases burst out, and then again a hesitation, and 'y'know'... As I see it, it's not necessary to mumble. He walks firmly enough... His motions - his movements - are punctilious; only nimble smooth speech God did not grant him." [«Говорит с запинкой, и вдруг вырываются фразы, и опять запинка и «тае»...Шамкать, мне кажется, не нужно. Ходит твердо;...Приемы-движения - истовые, только речи гладкой Бог не дал».] ${ }^{13}$ "Smooth speech" of the sort that "God did not give Akim" is the most stage-worthy vehicle for virtue. Perhaps if Shakespeare's jesters and fools were not so "smooth of speech," if they stuttered while walking firmly, they could also be for Tolstoy the vehicle of truth that they are for the rest of the world.

Let me close by returning to a point suggested at the beginning of this Postscript: that for Tolstoy as dramatist - and perhaps for Tolstoy in

12 One wonders whether Tolstoy's English simply could not grasp the Fool's subtleties - or if, on the contrary, subtlety itself was the problem. In "On Shakespeare and on Drama," Tolstoy expresses his irritation at Lear's "long and high-flown speeches" followed by his habit of summoning his Fool and eliciting his jokes, "notwithstanding the despair he has just manifested." The jokes themselves are not funny, Tolstoy insists, and "besides creating an unpleasant feeling similar to shame, the usual effect of unsuccessful witticisms, they are so drawn out as to be positively dull" (18). George Orwell picked up on this loathing for the Fool, put it in his title, and found it especially worthy of rebuttal: "Tolstoy sees no justification for the presence of the Fool," Orwell writes. [But] "the Fool is integral to the play. He acts not only as a sort of chorus, making the central situation clearer by commenting on it more intelligently than the other characters, but as a foil to Lear's frenzies. His jokes, riddles, and scraps of rhyme... are like a trickle of sanity running through the play." ("Lear, Tolstoy and the Fool," 40).

13 Tolstoy on 1887 March 5 to P. M. Svobodin [Kozienko], L. N. Tolstoi, PSS t. 64 Pis'ma (1953): 24. 
general - the truth of a situation was to be found in minds and bodies, not in words. A spectacular application of this hypothesis was tried in a production of The Realm of Darkness in 2010, by the Arts Program at Eugene Lang College in New York City. ${ }^{14}$ The entire production took place in a tiny interior space, with bleachers for the spectators lining two sides of the room and doors opening out left and right for the players. The crushing of Akulina's illegitimate baby under boards in the cellar was projected in black-and-white on a screen above the audience's head. By the Fifth Act, as Nikita is being driven wild by his own dissoluteness and acts of murder, the audience too begins to feel uncomfortably trapped. To the horror of his smooth-talking mother, Nikita confesses: first to Marinka, then to Akulina, finally to his father. When the police arrive to take Nikita away, father Akim, stuttering ecstatically, begs them to hold off: "God's work is being done, this is no time for your 'dictments... Speak, my child, don't be 'fraid o' people, God, God! He is here!" Nikita willingly submits to being tied up: "It was my idea, my doin'. Take me you know where."15

At that point and with that line, Tolstoy's play is over. But the production did not end. As soon as the final words were spoken, the dialogue (and the characters) ricocheted back to the beginning of Nikita's confession to Marinka. Then the final six or eight minutes of Act Five were replayed, perhaps a bit faster, but without change. Again we reached the end; again the action spun back to the critical moment, as if we were caught in a vortex - and the final confession rushed through us again, with an even greater degree of urgency. The audience on the bleachers had no idea when it would end, or how many repetitions it would take. Suddenly the roof opened up. Light poured in, on player and spectator alike. When finally the actors stopped on the final word, the moment of Nikita's full confession and Akim's ecstasy, still they did not release the play. They froze in place, and appeared ready to wait forever. We the spectators didn't know how to get out, or when to get out. Five minutes must have passed before someone looked at her watch and crept down off the bleachers for one of the side doors. Eventually the rest of the spectators picked their way down and out through the statues.

14 The Realm of Darkness, acting version derived from the Kantor-Tulchinsky translation. Designed and directed by Zishan Ugurlu, literary advisor Inessa Medzhibovskaya. La Mama Ellen Stewart Theater, New York City, March 4-7, 2010.

15 Leo Tolstoy, The Realm of Darkness, in Plays: Volume Two, 1886-1889. Translated by Marvin Kantor with Tanya Tulchinsky (Evanston: Northwestern University Press, 1996), 1-90, esp. 88-90. 
It was a fabulous rendition of Tolstoy's drama, fully in the spirit of its author. It was also squarely in the tradition of Russian drama, where frozen, shocked, or silenced endings are a trademark of moral urgency: the tableau at the end of Gogol's Government Inspector, the abandoned holy fool and unresolved chord at the end of Musorgsky's Boris Godunov, the announcement of Treplev's suicide at the end of Chekhov's Seagull. In this production, Shakespeare's accessible stage and direct appeal to the audience were in full force - for call it what you will, The Power of Darkness rises to Shakespearean heights. But there was no fanfare, no verbal adornment. And, of course, no formula to release the audience from the show, or to separate out their world from the pleasant fantasy of a stage. We have (literally) heard all the words before and can now cast them off. Realms of darkness, we were given to believe in this production, will go on forever until the vortex is punctuated with light. And then each member of the audience crawls out alone. Hoffman's film of The Last Station is easier on those who watch. It is linear, the performers have a script, the public knows what to do: follow the coffin in a mass procession to the grass-covered grave. But that night downstairs at La Mama, Tolstoy was everywhere. 